\title{
Treatment-sensitive HIV Infection
}

National Cancer Institute

\section{Source}

National Cancer Institute. Treatment-sensitive HIV Infection. NCI Thesaurus. Code

C156801.

An infection with human immunodeficiency virus that responds to therapy. 